\title{
Technology, Human Capital and Growth: Further Evidence from Threshold Cointegration
}

\author{
Nicholas Apergis* \\ Department of Banking and Financial Management, University of Piraeus, Piraeus, Greece
}

\begin{abstract}
This paper assesses whether the linkages between $R \& D$, human capital and productivity growth in a panel of EU manufacturing industries over the period 1980-2002 are affected by a critical level of human capital. To employ our data in an efficient manner, the study makes use of a dynamic threshold-based analysis, which determines endogenously the sample splitting procedure. The estimates indicate the presence of a threshold level based on the size-level of human capital. Countries with human capital levels above the threshold receive higher productivity growth benefits from higher R\&D.
\end{abstract}

JEL Classification: O40; L60; C23.

Keywords: Productivity growth, R\&D, Human capital, Threshold effects, Manufacturing industries, EU countries, Panel data.

\section{INTRODUCTION}

Recent theories of innovation-driven growth models have stressed the importance of innovation efforts as a key propagator of economic growth ${ }^{1}$. These models assume that spillover effects, generated by knowledge transmission mechanisms, are strong enough to maintain R\&D costs on a constant basis. This in turn allows sustained total factor productivity (TFP) growth. A number of studies explore empirically the contribution of R\&D spillovers to a country's TFP level, while a smaller body of empirical work examines the same issue at industry level by considering the international intra-industry R\&D spillovers [4]. Overall, the evidence suggests that $R \& D$ spillovers increase productivity of the country/industry $[5,6]$. A new group generation of R\&D-based studies considers a different approach that relates the two primary variables, which comes in two varieties, one that incorporates diminishing returns to the stock of knowledge in R\&D [7, 8] and the alternative, which considers a fully endogenous 'Schumpetarian' environment. According to this version, there are constant returns to the stock of knowledge in R\&D, which implies a close association between the behavior of R\&D and TFP growth. Within such an environment, R\&D is crucially needed to outweigh the negative impact of more product varieties on the association under study. [9-12] compare the above two alternative versions of the new generation models against the real world TFP trends over the post-war period. Their results provide support to the Schumpetarian version.

A shortcoming of the innovation-driven growth models is that they do not adequately consider the role of human

*Address correspondence to this author at the Department of Banking and Financial Management, University of Piraeus, Piraeus, Greece;

E-mail: napergis@unipi.gr

\footnotetext{
${ }^{1}$ See [1], [2], [3].
}

capital. This approach stems from the seminal works [13, 14], which employed the neoclassical theory of growth and introduced endogenous growth models. These models emphasize the mechanisms linked to the actual dynamics of growth. The empirical evidence on the role of human capital on growth has, however, generated mixed results. Although the majority of empirical efforts have shown that human capital, being a complementary factor with technological capital, yields positive effects in fostering technological change, diffusion, and, thus, growth [15-20]; and others have yielded disappointing results about the role of human capital in the relevant process. [21-28] have attempted to rationalize this mixed evidence by claiming that it could be the outcome of econometric difficulties when specifying growth regressions. [29-32] claim that the differentiation in the empirical finding is probably due to the presence of the bias generated by the mis-measurement of schooling data, while $[33,34]$ attribute it to the fact that educational indicators seem to disregard differences in educational quality. [35] attributes it to omitted variables in the relevant regressions, while they emphasize the importance of reverse causation from expected growth to schooling.

Human capital, capable of working with the new technologies created by innovation efforts, facilitates the realization of $R \& D$ spillovers. Moreover, it accounts for innovations different from the R\&D sector. In other words, models that do not account for an explicit role for human capital fail to consider the need for the presence of qualified labor, qualified enough to work with the new technologies created by innovation efforts. The complementary character between R\&D activities and human capital has been emphasized. [36-40] developed theoretical models where the steady-state rate of growth is determined by the rate of R\&D investment and human capital accumulation. A large stock of human capital facilitates the absorption of new products and new ideas and discoveries [41, 42]. On the empirical basis, [43] consider explicitly the role of human capital and they 
conclude that its omission results in overestimation of the R\&D coefficients. However, they provide contradictionary results as to the impact of human capital on TFP. The same picture emerges when it comes to international intra-industry studies (e.g. [4] $)^{2}$.

The studies mentioned above have assumed a linear relationship between the two variables under investigation. [45-48] emphasize threshold externalities between certain variables, such as human capital, and economic growth. A relatively recent study, [49] investigates the nexus between economic growth and human capital by allowing for the presence of a non-linear relationship between the two variables. Their findings validate the presence of nonlinearity. However, to the best of our knowledge, only a handful of studies have investigated so far whether the linkages of R\&D spillovers, human capital and TFP (used as a proxy for growth) are affected by the level of human capital available in each country. [50,51] argue that different levels of human capital vary in the extent to which they facilitate technology absorption and, therefore, affect the speed of growth. In particular, low human capital levels do not allow a country or an industry to take advantage of the 'incorporated' knowledge via domestic and foreign R\&D diffusions. In other words, R\&D spillovers tend to have a stronger growth enhancing effect where the population has higher education above an estimated threshold. As claimed by [52], this would suggest a non-linear process, which indicates that the efficiency of economies in benefiting from new technologies depends critically on their absorption capacity that is crucially determined by the level of knowledge [53]. [39] and [40] also argue that there exists a critical level of human capital above and below which the impact of $\mathrm{R} \& \mathrm{D}$ on productivity growth differs. Consequently, the novelty of the paper is to explore such a dynamic complementarity of R\&D spillovers and human capital and its impact on total factor productivity (TFP) for a number of European Union countries across industries, in a non-linear fashion through recent methodological approaches, such as threshold cointegration methodologies.

To this end, the paper makes use of a threshold estimation procedure, suggested in [54], who recommend a methodology that allows estimation of a cointegrating relationship and a single threshold when both are unknown in an error correction model (ECM). Their methodology with one cointegrating vector and a single threshold effect is based on a Langrange Multiplier (LM) test (the so called supLM test) for the presence of a threshold. According to this test, the null hypothesis of linearity is tested against the alternative of threshold cointegration. On the modeling front, we use [55] model specification, where long-run growth is endogenously driven by $R \& D$ investments. However, the model is extended to consider the role of human capital in enhancing $R \& D$ spillovers.

The rest of the paper is organized as follows: The following section presents the econometric specification and

\footnotetext{
${ }^{2}$ [4] uses the Barro and Lee [41] human capital database, while. [44] relies on human capital estimates from the de la Fuente and Doménech [32] database.
}

data used. Econometric methodology and empirical estimates are reported in the next section. The final section concludes the paper.

\section{MODEL SPECIFICATION AND DATA}

To identify the non-linearity that describes the R\&D spillovers-productivity growth relationship we make the assumption that productivity growth can be enhanced through a higher portion of human capital in the production line combined with $R \& D$ activities. This is a valid argument since the knowledge can be transmitted through such R\&D activities. Next, we make the hypothesis that human capital affects productivity growth through its favorable impact on R\&D; the productivity payoffs from R\&D are mediated by the level of human capital reached. Moreover, we make the assumption that there exists some critical levels of human capital above and below in which the positive contribution of R\&D to productivity growth differs. In particular, we are making the assumption that the productivity growth response to increased R\&D will be greater for those countries with higher human capital than those with lower human capital. Thus, the relationship between R\&D and human capital may be non-linear rather then linear. Assuming a single threshold, the TFP growth equation yields:

$$
\begin{aligned}
& \Delta \log \mathrm{F}_{\mathrm{ijt}}=\beta_{0 \mathrm{ij}}+\beta_{1} \Delta \log H C_{\mathrm{ij}}+\beta_{2} \mathrm{I}\left(\Delta \log H \mathrm{C}_{\mathrm{it}} \leq \gamma\right) \Delta \log \mathrm{S}_{\mathrm{ijt}}+\beta_{3} \\
& \mathrm{I}\left(\Delta \log H \mathrm{C}_{\mathrm{it}}>\gamma\right) \Delta \log \mathrm{S}_{\mathrm{ijt}}+\varepsilon_{\mathrm{ijt}}
\end{aligned}
$$

or

$\Delta \mathrm{f}_{\mathrm{ijt}}=\beta_{0 \mathrm{ij}}+\beta_{1} \Delta \mathrm{hc}_{\mathrm{ijt}}++\beta_{2} \mathrm{I}(\mathrm{hc} \leq \gamma) \Delta \mathrm{s}_{\mathrm{ijt}}+\beta_{3} \mathrm{I}\left(\mathrm{hc}_{\mathrm{it}}>\gamma\right) \Delta \mathrm{s}_{\mathrm{ijt}}+$ $\varepsilon_{\mathrm{ijt}}$

where subscript $i$ refers to the country, $j$ to the industry and $t$ to time; $F$ represents total factor productivity (TFP); $S_{i j t}$ is the technology effect; $\mathrm{HC}_{\mathrm{ijt}}$ is human capital. The indicator function I sorts the data to create various sub-samples; $\varepsilon_{i j}$ is i.i.d. error term. According to (1), human capital is treated as another input in an underlying Cobb-Douglas production function. The threshold model addresses the following problems: i) how to jointly estimate the threshold value $\gamma$ and the slope coefficients $\beta_{1}, \beta_{2}$, and $\beta_{3}$ ii) how to test whether such a single threshold does exist.

Our sample consists of nine European countries (Great Britain, Finland, France, Germany, Italy, Belgium, Netherlands, Spain and Portugal) and 21 manufacturing industries in each country over the period 1980-2002. The size of our sample as well as the time span was mainly determined by the availability of $R \& D$ investment and human capital data. The same International System of Industries Classification code was used in all industry-level data sources. The manufacturing industries and their ISIC codes are presented in the Appendix.

To control for data quality and, therefore, draw sharp inferences we employ human capital estimates from both $[56,57]$ and [58] databases. Data comes from the EU KLEMS database provided by the University of Groningen. The human capital data is provided at country level and of 5yearly average. It is not available on an industry level. We interpolate between five-yearly and extrapolate observations 
using STATA's linear interpolation (extrapolation) function. We have to combine this data with the country-industry level data by repeating it every time we utilize industry level data. Import measures, such as imports from the whole word, were also obtained from the [59] Bilateral Trade Database. All price figures are expressed in euros at 1995 purchasing power parity (PPP). The estimations and test procedures make use of GAUSS software.

\section{ECONOMETRIC METHODOLOGY EMPIRICAL RESULTS}

AND

\section{Unit Root Tests}

The null hypothesis of non-stationarity versus the alternative that the variable is stationary is tested using the group mean panel unit root test (or 't-bar' test) of Im et al. [60]. This test is based on the Augmented Dickey-Fuller (ADF) statistic [61] and allows each member of the cross section to have a different autoregressive root and different autocorrelation structures under the alternative hypothesis. The results are reported without and with a trend in Table $\mathbf{1 .}$ The hypothesis that all the variables contain a unit root is accepted at the $1 \%$ significant level, suggesting that all the $\log$ variables in our study are I(1).

Table 1. Unit Root Tests

\begin{tabular}{|c|c|c|c|c|}
\hline \multirow{2}{*}{ Variables } & W/o Trend & W/ Trend & W/o Trend & W/Trend \\
\hline & \multicolumn{2}{|c|}{ Levels } & \multicolumn{2}{|c|}{ First Differences } \\
\hline $\mathrm{f}$ & $-0.34(3)$ & $-0.64(3)$ & $-10.36(2)^{*}$ & $-11.25(2)^{*}$ \\
\hline hc & $-2.11(3)$ & $-2.46(2)$ & $-6.55(2)^{*}$ & $-7.12(1)^{*}$ \\
\hline $\mathrm{s}$ & $-2.02(3)$ & $-2.37(3)$ & $-7.63(1)^{*}$ & $-10.62(2)^{*}$ \\
\hline
\end{tabular}

Notes: $\mathrm{f}=$ the $\log$ of total factor productivity, $\mathrm{hc}=$ the $\log$ of human capital, and $\mathrm{s}=$ the $\log$ of R\&D expenses. Figures in brackets denote the number of lags in the augmented term that ensures white-noise residuals. The optimal lag length was determined through the Akaike information Criterion (AIC) and the Schwarz-Bayes Information Criterion (SBIC).

* Significant at $1 \%$.

\section{Cointegration Tests}

Panel cointegration tests, based on [62] Fully Modified OLS (FMOLS) tests and reported in Table 2, reveal the presence of a long-run relationship among the variables of total factor productivity, human capital and R\&D expenses and the employment of an Error Correction (EC) model must be followed. Thus, model (1)' in an EC form yields:

$\Delta \mathrm{f}_{\mathrm{ijt}}=\beta_{0 \mathrm{ij}}+\beta_{1} \Delta \mathrm{hc}_{\mathrm{ijt}}++\beta_{2} \mathrm{I}(\mathrm{hc} \leq \gamma) \Delta \mathrm{s}_{\mathrm{ijt}}+\beta_{3} \mathrm{I}\left(\mathrm{hc}_{\mathrm{it}}>\gamma\right) \Delta \mathrm{s}_{\mathrm{ijt}}+$ $\beta_{4} \mathrm{EC}_{\mathrm{ij}(\mathrm{t}-1)}+\varepsilon_{\mathrm{ijt}}$

(1)"

Table 2. Cointegration Tests

\begin{tabular}{|c|c|}
\hline Panel v-stat & $27.684413^{*}$ \\
\hline Panel rho-stat & $-27.155982^{*}$ \\
\hline Panel pp-stat & $-26.353791^{*}$ \\
\hline Panel adf-stat & $-9.347736^{*}$ \\
\hline Group rho-stat & $-27.274034^{*}$ \\
\hline Group pp-stat & $-27.190045^{*}$ \\
\hline Group adf-stat & $-9.793459^{*}$ \\
\hline Notes: An asterisk denotes the rejection of the null hypothesis of no cointegration.
\end{tabular}

\section{Threshold Cointegration Estimations}

Once cointegration among the three variables under investigation was identified and to remain consistent with the threshold model (1) or (1)' we make use of the methodology of threshold cointegration, which allows non-stationary variables to be modeled accordingly. In particular, the methodology of threshold cointegration combines both nonlinearity and cointegration. This particular methodology is necessary to explain the long-run equilibrium relationship by a cointegration test, while assuming the feature of asymmetric adjustment. The linear case assumes the tendency to move towards the long-run equilibrium for every time period, the asymmetric or threshold case emphasizes the possibility that movements towards the long-run equilibrium need not occur in every period. Thus, there exists a discrete adjustment to equilibrium only when the deviation from the equilibrium exceeds a critical threshold. Threshold cointegration could characterize the discrete adjustment in terms of the case where the long-run relationship does not hold inside a certain band, but then remains active if the system gets too far from the equilibrium. However, for this methodology to be materialized the estimation of the cointegrating vector must be observable for the grid research to be clear. To this end, [54] suggest a methodology that allows estimation of a cointegrating relationship and a single threshold (as in our case) when both are unknown in an error correction model (EC). They propose a methodology with one cointegrating vector and a single threshold effect based on a Langrange Multiplier (LM) test (the so called supLM test) for the presence of a threshold. According to this test, the null hypothesis of linearity is tested against the alternative of threshold cointegration.

In addition, to ensure that the threshold estimations include sufficient observations in one of the regimes, we restrict the minimization problem to values of $\gamma$ such that at least $1 \%$ of the observations lie in both regimes. The lag length selection of the model is determined by the Akaike criterion, leading to the results of 1 lag at both the case of the Barro \& Lee definition and of the de la Fuente and Doménech definition of human capital. Table 3 reports the dynamic long-run results. The results are reported under both alternative human capital measures. The first column reports the results under the Barro \& Lee measure. The point estimate of the threshold $\gamma$ is equal to 9.2991 or 9.3 years. The human capital coefficient is shown to be positive (0.074), which is consistent with theoretical arguments supporting a positive effect of this variable on growth. However, the R\&D interaction coefficient turns out to be statistical significant only in the case where human capital exceeds the endogenously determined threshold. Below this critical or threshold level the impact of $R \& D$ growth turns to be insignificant. Therefore, if the value of the human capital stock exceeds 9.3 years, each percentage point increase in R\&D growth leads to a 0.042 percentage point increase in TFP growth. The second column of Table 3 replicates the estimations under an alternative definition of human capital, the one provided by de la Fuente and Doménech. The results lend support to those reached before. More specifically, the 
Table 3. Estimations of the Threshold Productivity Growth Model

\begin{tabular}{|l|c|c|}
\hline \multicolumn{1}{|c|}{ HC } & Barro \& Lee & de la Fuente and Doménech \\
\hline \hline Constant & $-0.036(2.11)^{*}$ & $-0.027(2.36)^{*}$ \\
\hline$\Delta \log \mathrm{HC}_{\mathrm{ij}(\mathrm{t}-\mathrm{l})}$ & $0.074(4.06)^{* *}$ & $0.093(3.79)^{* *}$ \\
\hline$\Delta \log \mathrm{F}_{\mathrm{ij}(\mathrm{t}-\mathrm{l})}$ & $0.336(4.23)^{* *}$ & $0.341(4.17)^{* *}$ \\
\hline$\Delta \log \mathrm{S}_{\mathrm{ij}(\mathrm{t}-\mathrm{l})} \mathrm{I}(\Delta \log \mathrm{HC} \leq \gamma)$ & $0.016(1.24)$ & $0.021(1.37)$ \\
\hline$\Delta \log \mathrm{S}_{\mathrm{ij}(\mathrm{t}-\mathrm{l})} \mathrm{I}(\Delta \log \mathrm{HC}>\gamma)$ & $0.042(3.49)^{* *}$ & $0.049(3.65)^{* *}$ \\
\hline $\mathrm{EC}_{\mathrm{ij}(\mathrm{t}-1)}$ & $-0.045(-4.77)^{* *}$ & $-0.051(-5.49)^{* *}$ \\
\hline Threshold Value $(\%)$ & $9.2991 \approx 9.3$ & $9.4356 \approx 9.4$ \\
\hline Observations & 2268 & 2268 \\
\hline Adjusted $\mathrm{R}^{2}$ & 0.36 & 0.33 \\
\hline supLM & $6.12[\mathrm{p}=0.00]$ & $6.74[\mathrm{p}=0.00]$ \\
\hline F-statistic & $23.54 * *$ & $20.11 * *$ \\
\hline
\end{tabular}

Notes: The F-statistic tests the null that all coefficients are jointly equal to zero. SuplM is is the Hansen and Seo [54] statistic. The results reject the null hypothesis of no threshold (linearity).

* Significant at the 5 percent level.

** Significant at the 1 percent level.

human capital coefficient is shown to be positive again (0.093), while the threshold estimation turns to be now 9.4356 or 9.4 years. Thus, if the value of the human capital stock exceeds 9.4 years, each percentage point increase in $\mathrm{R} \& \mathrm{D}$ growth leads to a 0.049 percentage point increase in TFP growth.

Moreover, in both cases the effect of R\&D expenses on TFP growth in the second regime is stronger than in the first regime in terms of the coefficient size. The second regime occurs when the human capital value exceeds the threshold. This is the regime with the lower number of observations representing the $37.5 \%$ of the total sample. Finally, the supLM statistic, proposed by [54], is also reported along with its associated asymptotic p-value calculated using the fixed regressor boot-strap proposed by [63], with 10,000 replications. This statistic tests the null hypothesis of a linear model against the threshold specification. As it can be seen from the results in Table 3, the null hypothesis is clearly rejected in favor of threshold cointegration.

Table 4 provides some robustness tests of the estimated link between TFP growth and R\&D by adding the imports share as a control variable in the relevant regression:

$\Delta \log \mathrm{F}_{\mathrm{ijt}}=\delta_{0 \mathrm{ij}}+\delta_{1} \Delta \operatorname{logHC_{\mathrm {ijt}}}+\delta_{2} \mathrm{I}\left(\Delta \operatorname{logHC} \mathrm{C}_{\mathrm{it}} \leq \gamma\right) \Delta \log \mathrm{S}_{\mathrm{ijt}}+\delta_{3}$ $\mathrm{I}\left(\Delta \log \mathrm{HC}_{\mathrm{it}}>\gamma\right) \Delta \log \mathrm{S}_{\mathrm{ijt}}+\delta_{4} \Delta \log \mathrm{IMP}_{\mathrm{ijt}}+\delta_{5} \mathrm{EC}_{\mathrm{ij}(\mathrm{t}-1)}+\eta_{\mathrm{ijt}}$

or

$\Delta \mathrm{f}_{\mathrm{ijt}}=\delta_{0 \mathrm{ij}}+\delta_{1} \Delta \mathrm{hc}_{\mathrm{ijt}}+\delta_{2} \mathrm{I}\left(\mathrm{fc}_{\mathrm{it}} \leq \gamma\right) \Delta \mathrm{s}_{\mathrm{ijt}}+\delta_{3} \mathrm{I}\left(\mathrm{fc}_{\mathrm{it}}>\gamma\right) \Delta \mathrm{s}_{\mathrm{ijt}}+\delta_{4}$ $\Delta \mathrm{imp}_{\mathrm{ijt}}+\delta_{5} \mathrm{EC}_{\mathrm{ij}(\mathrm{t}-1)}+\eta_{\mathrm{ijt}}$

The import share captures the impact of international

Table 4. Robustness Estimates of the Threshold Productivity Growth Model

\begin{tabular}{|c|c|c|}
\hline HC & Barro \& Lee & de la Fuente and Doménech \\
\hline Constant & $-0.0081(2.43)^{*}$ & $-0.0061(2.71)^{* *}$ \\
\hline$\Delta \log \mathrm{HC}_{\mathrm{ij}(\mathrm{t}-\mathrm{l})}$ & $0.065(4.62)^{* *}$ & $0.078(4.18)^{* *}$ \\
\hline$\Delta \log \mathrm{F}_{\mathrm{ij}(\mathrm{t}-1)}$ & $0.297(4.48)^{* *}$ & $0.314(4.73)^{* *}$ \\
\hline$\Delta \log \mathrm{IMP}_{\mathrm{ij}(\mathrm{t}-\mathrm{l})}$ & $0.052(3.83)^{* *}$ & $0.059(4.07)^{* *}$ \\
\hline$\Delta \log \mathrm{S}_{\mathrm{ij}(\mathrm{t}-1) \mathrm{I}} \mathrm{I}(\Delta \log \mathrm{HC} \leq \boldsymbol{\gamma})$ & $0.014(1.08)$ & $0.016(1.18)$ \\
\hline$\Delta \log S_{\mathrm{ij}(\mathrm{t}-1)} \mathrm{I}(\Delta \log \mathrm{HC}>\gamma)$ & $0.053(4.20)^{* *}$ & $0.060(3.92)^{* *}$ \\
\hline $\mathrm{EC}_{\mathrm{ij}(\mathrm{t}-1)}$ & $-0.037(6.33)^{* *}$ & $-0.040(5.19)^{* *}$ \\
\hline Threshold Value (\%) & $9.2995 \approx 9.3$ & $9.4521 \approx 9.4$ \\
\hline Observations & 2268 & 2268 \\
\hline Adjusted $\mathrm{R}^{2}$ & 0.38 & 0.37 \\
\hline supLM & $7.14[\mathrm{p}=0.00]$ & $7.68[\mathrm{p}=0.00]$ \\
\hline F-statistic & $26.79 * *$ & $24.51 * *$ \\
\hline
\end{tabular}


trade on the relationship under investigation [64-66]. Emphasis is given on the role of imports since they could affect both innovation and technology transfers. Imports embody foreign technology and could raise an industry's output through reverse-engineering. As industries successfully imitate imported goods, they gain more insight as to how these goods are engineered, and can improve upon. In other words, imitation of foreign technology improves the chances of invention as well [67]. In addition [68] argues that imports should be considered alone on the grounds that imported intermediate and capital goods embody new technologies.

The results are reported again under both alternative human capital measures. The technology coefficient is shown again to exert a positive impact on the rate of growth in both definitions, while the R\&D interaction coefficient turns out to be statistical significant again only in the case where human capital exceeds an endogenously determined threshold level. If the value of the human capital stock exceeds 9.3 years, each percentage point increase in $R \& D$ growth leads to a 0.053 percentage point increase in TFP growth under the Barro \& Lee human capital measure. Under the de la Fuente and Doménech human capital measure the threshold turns to be 9.5 years. Thus, if the value of the human capital stock exceeds 9.5 years, each percentage point increase in R\&D growth leads to a 0.060 percentage point increase in TFP growth. The coefficient of imports share is positive in both alternative human capital measurements, which validates the reverse-engineering hypothesis. Once again, in both cases the effect of R\&D expenses on TFP growth in the second regime is stronger than in the first regime in terms of the coefficient size. Finally, the supLM statistic displays that again the null hypothesis is clearly rejected in favor of threshold cointegration.

\section{CONCLUSIONS}

The results of this study provide some insights into the relative importance of the joint role of human capital in economic growth in models that consider the explicit role of technological knowledge spillovers. Using appropriate human capital data, econometric techniques that apply a threshold cointegration model that considers the possibility of a non-linear relationship between TFP growth, human capital and R\&D expenses, the cross-country and crossindustries empirical findings for ten European countries over the period 1980-2002 provide evidence in favor not only of the inclusion of human capital as an explanatory variable in explaining TFP behavior, but also in favor of the presence of threshold effects on human capital in the technologyproductivity growth link, that is, whether human capital above a threshold level allows certain channels of technology diffusion to have a greater impact on productivity growth.

Accordingly, the empirical findings show that countries with human capital level above the threshold receive higher productivity benefits from increased $R \& D$. The interpretation of the non-linear relationship between productivity growth and TFP needs some discussion and further research is more than a necessity. A tentative explanation may be the relative importance of absorptive capacity for industries that use high skilled human capital and are in a better position to exploit knowledge spillovers, thus, reducing costs of production. The results may be of high interests not for industries themselves but also for policy makers who design and support educational systems in identifying the mechanism of TFP growth dependencies on the interaction of human capital and R\&D expenses. Further research analysis on a firm-based status could shed more light on this issue since the hypothesis of identical firms within industries cannot be accepted without any doubt.

\section{APPENDIX}

\section{Manufacturing Industries and ISIC Codes}

\begin{tabular}{|l|c|c|}
\hline \multicolumn{1}{|c|}{ Manufacturing Industries } & Abbreviation & $\begin{array}{c}\text { ISIC Code } \\
\text { (Rev. 3) }\end{array}$ \\
\hline \hline Food products, beverages and tobacco & FOD & $15-16$ \\
\hline $\begin{array}{l}\text { Textiles, textiles products, leather and } \\
\text { footwear }\end{array}$ & TEX & $17-19$ \\
\hline Wood and products of wood and cork & WOD & 20 \\
\hline $\begin{array}{l}\text { Pulp, paper, paper products, printing } \\
\text { and publishing }\end{array}$ & PAP & $21-22$ \\
\hline $\begin{array}{l}\text { Coke, refined petroleum products and } \\
\text { nuclear fuel }\end{array}$ & COK & 23 \\
\hline Chemicals excluding pharmaceuticals & CHE & 24 less 2423 \\
\hline Pharmaceuticals & PHA & 2423 \\
\hline Rubber and plastics products & RUB & 25 \\
\hline Other non-metallic mineral products & ONM & 26 \\
\hline Iron and steel & IAS & $271+2731$ \\
\hline Non-ferrous metals & NFM & $272+2732$ \\
\hline $\begin{array}{l}\text { Fabricated metal products } \\
\text { (excluding machinery and equipment) }\end{array}$ & FAB & 28 \\
\hline Machinery and equipment, n.e.c. & MAC & 29 \\
\hline $\begin{array}{l}\text { Office, accounting and computing } \\
\text { machinery }\end{array}$ & OFF & 30 \\
\hline $\begin{array}{l}\text { Electrical machinery and apparatus, } \\
\text { n.e.c. }\end{array}$ & ELE & 31 \\
\hline $\begin{array}{l}\text { Radio, television and } \\
\text { communication equipment }\end{array}$ & AIR & 353 \\
\hline $\begin{array}{l}\text { Medical, precision and optical } \\
\text { instruments }\end{array}$ & MED \\
\hline Mother Manufacturing \\
\hline Recycling)
\end{tabular}

\section{REFERENCES}

[1] Romer PM. Endogenous technological change. J Polit Econ 1990; 98: 71-102. 
[2] Rivera-Batiz LA, Romer PM. Economic integration and economic growth. Q J Econ 1991; 106: 531-56.

[3] Grossman G , Helpman E. Innovation and growth in the global economy. Cambridge MA \& London UK: MIT Press 1991.

[4] Griffith RS. Redding J, van Reenen J. Mapping the two faces of $\mathrm{R} \& \mathrm{D}$ : productivity growth in a panel of OECD Industries. Rev Econ Stat 2004; 86: 883-95.

[5] Zachariadis M. R\&D innovation and technological progress: a test of the schumpetarian framework without scale effects. Can J Econ 2003; 36: 566-86.

[6] Madsen JB. Semi-endogenous versus schumpetarian growth models: testing the knowledge production function using international data. J Econ Growth 2008; 13: 1-26.

[7] Kortum S. Research patenting, and technological change. Econometrica 1997; 65: 1389- 419.

[8] Segerstrom PS. Endogenous growth without scale effects. Am Econ Rev 1998; 88: 1290-310.

[9] Howitt P. Steady endogenous growth with population and R\&D inputs growing. J Polit Econ 1999; 107: 715-30.

[10] Peretto PF, Smulders S. Technological distance, growth and scale effects. Econ J 2002; 112: 603-24.

[11] Laincz CA, Peretto PF. Scale effects in endogenous growth theory: an error of aggregation not specification. Drexel University and Duke University: Mimeo 2004.

[12] Ha J, Howitt P. Accounting for trends in productivity and R\&D: a schumpetarian critique of semi-endogenous growth theory. J Money Credit Bank 2008; 39: 733-74.

[13] Romer PM. Increasing returns and long-run growth. J Polit Econ 1986; 94: 1002- 37.

[14] Lucas R. On the mechanics of economic development. J Monet Econ 1998; 22: 3-41.

[15] Mankiw N, Romer D, Weil DA. Contribution to the empirics of economic growth. Q J Econ 1992; 107(2): 407-38.

[16] Barro R, Lee J. International data on educational attainment: updates and implications. Oxf Econ Pap 2001; 53: 541-63.

[17] Gould D, Ruffin R. Human capital, trade, and economic growth. Weltwirtschaftliches Arch 1995; 131: 425-35.

[18] Berthelemy JC, Dessus S, Varoudakis A. Human capital and growth: the role of the trade regime. Mimeo, OECD Development Centre, Paris 1997.

[19] de la Fuente A, Ciccone A. Human capital in a global and knowledge-based economy. Final report, European Commission 2002.

[20] Sianesi B, van Reenen J. The returns to education: Macroeconomics. J Econ Surv 2003; 17: 157-200.

[21] Benhabib J, Spiegel M. Human capital and technology diffusion. In: Aghion P, Durlauf S, Eds. The handbook of economic growth. Amsterdam, The Netherlands, North Holland: Elsevier 2005.

[22] Pritchett L. Divergence, big time. Paper No. 1522, Country Economics Department, World Bank, 1995.

[23] Pritchett L. Where has all the education gone? World Bank Econ Rev 2001; 15: 367-91.

[24] Caselli F, Esquivel G, Lefort F. Reopening the convergence debate: a new look at cross-country growth empirics. J Econ Growth 1996; 1: 363-89.

[25] Klenow P, Rodriguez-Clare A. The neoclassical revival in growth economies: has it gone too far? In: Bernanke BS, Rotemberg JJ, Eds. Chapter 2 in NBER Macroeconomic Annual. Cambridge, MA: MIT Press 1997.

[26] Aghion P, Howitt P. Endogenous growth theory. Cambridge, Mass: MIT Press 1988

[27] Temple J. The new growth evidence. J Econ Lit 1999; 37: 112-56.

[28] Durlauf SN, Johnson P, Temple J. Growth econometrics. In: Aghion P, Durlauf S, Eds. The handbook of economic growth. Amsterdam, The Netherlands, North Holland: Elsevier 2005.

[29] Krueger AB, Lindahl M. Education for Growth: why and for whom? J Econ Lit 2001; 39: 1101-36.

[30] Cohen D, Soto M. Growth and human capital: good data, good results. J Econ Growth 2007; 12: 51-76.

[31] de la Fuente A, Doménech R. Schooling data, technical diffusion and the neoclassical model. Am Econ Rev Pap Proc 2001; 90: 3237 .

[32] de la Fuente A, Doménech R. Human capital in growth regressions: how much difference does data quality make? CEPR Discussion Paper No. 2466, 2000.
[33] Hunushek EA, Kimko DD. Schooling, labor-force quality, and the growth of nations. Am Econ Rev 2000; 90: 1184-208.

[34] Barro R. Human capital and growth. Am Econ Rev Pap Proc 2001; 113: 12-7.

[35] Bils M, Klenow PJ. Does schooling cause growth? Am Econ Rev 2000; 90: 1160-83.

[36] Redding S. The low-skill, low-quality trap: strategic complementarities between human capital and R\&D. Econ J 1996; 106: 458-70.

[37] Autor DH, Katz LF, Kreuger AB. Computing inequality: have computers changed the labor market? Q J Econ 1998; 63: 1169213.

[38] Berman E, Bound J, Machin S. Implications of skilled- biased technological change: international evidence. Q J Econ 1998; 113: 1245-79.

[39] Borensztein E, De Gregorio J, Lee JW. How does fdi affect economic growth? J Int Econ 1998; 45: 115-35.

[40] $\mathrm{Xu}$ J. Multinational enterprises, technology diffusion and host country productivity growth. J Dev Econ 2000; 62: 477-93.

[41] Barro R, Lee J. International measures of schooling years and schooling quality. Am Econ Rev 1996; 86: 218-23.

[42] Teixeira AAC, Fortuna N. Human capital, innovation capability and economic growth in Portugal. Portugal Econ J 2004; 3: 200525.

[43] Benhabib J, Spiegel M. The role of human capital in economic development: evidence from aggregate cross- country data. J Monet Econ 1994; 34: 143-73.

[44] Barrio-Castro del T, Lopez-Bazo E , Serrano-Domingo G. New evidence on international R \& D spillovers, human capital and productivity in the OECD'. Econ Lett 2002; 77: 41-5.

[45] Durlauf SN, Johnson P. Multiple regimes and cross-country growth behaviour. J Appl Econ 1995; 10: 365-84.

[46] Quah DT. Empirics for economic growth and convergence. Eur Econ Rev 1996; 40: 1353-75.

[47] Easterly W, Levine R. Africa's growth tragedy: policies and ethnic divisions. Q J Econ 1997; 112: 1203-50.

[48] Liu T, Stengos T. Non-linearities in cross country growth regressions: a semiparametric approach. J Appl Econ 1999; 14: 527-38.

[49] Kalaitzidakis P, Mamuneas T, Savvides A, Stengos T. Measures of human capital and nonlinearities in economic growth'. J Econ Growth 2001; 6: 229-54.

[50] Acemoglu D. Patterns of skill premia. Rev Econ Stud 2003; 70: 199-230.

[51] Caselli F , Coleman WJ II. The world technology Frontier. Am Econ Rev 2006; 96: 499-522.

[52] Baldwin RE, Spergami F. Non-linearity in openness and growth link: theory and evidence. Geneva: Graduate Institute of International Studies 2000.

[53] Audretsch D, Feldman M. R\&D spillovers and the geography of innovation and production. Am Econ Rev 1996; 86: 630-40.

[54] Hansen BE, Seo B. Testing-for-two regime threshold cointegration in vector error-correction models' J Econom 2002; 110: 293-318.

[55] Keller W. Trade and the transmission of technology. J Econ Growth 2002; 7: 5-24.

[56] Barro R, Lee J. Sources of economic growth. Carnegie rochester conferences series on public policy 1994; vol. 40: pp. 1-46.

[57] Barro R,Lee J. International comparisons of educational attainment. J Monet Econ 1993; 32: 363-94.

[58] de la Fuente A, Doménech R. Human capital in growth regressions: how much difference does data quality make?. J Eur Econ Assoc 2006; 4: 1-25.

[59] Organization for Economic Co-operation and Development STAN Database for Industrial Analysis. OECD Statistical Compendium, CD-ROM, 2002.

[60] Im KS, Pesaran MH, Shin Y. Testing for unit roots in heterogeneous panels'. Working Paper 9526. Department of Applied Economics, Cambridge University 1995.

[61] Dickey DA, Fuller WA. Likelihood Ratio Statistics for Autoregressive Time Series with a Unit Root. Econometrica 1981; $49: 1057-72$.

[62] Pedroni P. Critical values for cointegration tests in heterogeneous panels with multiple regressors. Oxford Bull Econ Stat 1999; 61: 653-70.

[63] Hansen BE. Inference when a nuisance parameter is not identified under the null hypothesis. Econometrica 1996; 64: 413-30. 
[64] Ben-David D, Loewy M. Free trade, growth and convergence. J Econ Growth 1998; 32: 143-70.

[65] Frankel J, Romer D. Does trade cause growth? Am Econ Rev 1999; 89: 379-99.

[66] Cameron G, Proudman J, Redding S. Technological convergence. R\&D, Trade and productivity growth. Eur Econ Rev 2005; 49: 775807.
[67] Connolly M. The dual nature of trade: measuring its impact on imitation and growth. Working Paper No. 97-34, Duke University 1998

[68] Coe D, Helpman E, Hoffmaister A. North-South R\&D Spillovers. Econ J 1997; 107: 134-50.

(C) Nicholas Apergis; Licensee Bentham Open.

This is an open access article licensed under the terms of the Creative Commons Attribution Non-Commercial License (http://creativecommons.org/licenses/by-nc/ 3.0/) which permits unrestricted, non-commercial use, distribution and reproduction in any medium, provided the work is properly cited. 